\title{
Import Components and Import Multipliers in Indonesian Economy: World Input-Output Analysis
}

\author{
M. Muchdie ${ }^{1}$, M. Handry Imansyah ${ }^{2}$, M. Kusmawan ${ }^{3}$, Hamid Al-Jufri ${ }^{1}$ \\ ${ }^{1}$ Universitas Muhammadiyah Prof. DR. HAMKA, Jakarta: Post Graduate School \\ ${ }^{2}$ Universitas Lambung Mangkurat, Banjarmasin: School of Graduate Studies \\ ${ }^{3}$ Sekolah Tinggi Ilmu Ekonomi Ahmad Dahlan, Jakarta: Post Graduate Program \\ E-mail: eidmuchdie@uhamka.ac.id
}

Received: November 28, 2017; Accepted: January 19, 2018; Published: February 2, 2018

Permalink/DOI: http://dx.doi.org/10.17977/um002v10i12018p088

\begin{abstract}
This paper calculates, presents and discusses on import components and the impact of final demand change on Indonesian imports using Indonesian 36 sector input-output tables of years: 2000, 2005, 2010 and 2014 from World Input-Output Tables. The results showed that firstly, Indonesian import components of input were, on average, more than 20 percent; meaning that input that locally provided were less than 80 percent. Secondly, Indonesian import of input had increased significantly from US\$ 36,011 million in 2000 to US\$151,505 million in 2014. Thirdly, Indonesian imports have been dominated by Sector-3: Manufacture of food products, beverages and tobacco products, Sector-4: Manufacture of textiles, wearing apparel and leather products, Sector-24: Construction, Sector-25: Wholesale and retail trade and repair, and Sector-26: Transportation and post services. Fourthly, by country of origin, Indonesian imports have been dominated by Japan, Korea, the USA, Australia, and China. Imports from Australia, Japan, and the US have been decreased significantly, but import from China has steadily increased. Finally, highest sectoral import multipliers occurred if final demands change in Sector-1: Crop and animal production, forestry, fishing and aquaculture, Sector-2: Mining and quarrying, Sector-23: Water collection; sewerage; waste collection, treatment and disposal activities, and Sector-30: Real estate activities, but there was no significant difference of import multipliers for country origin of import.
\end{abstract}

Keywords: import components, sectoral import multiplier, spatial import multiplier.

JEL Classification: C67, D57, F17

\section{INTRODUCTION}

Indonesia is the largest archipelago in the world. It consists of five major islands and about 30 smaller groups. There are total numbers of 17,508 islands of which about 6000 are inhabited. Straddling equator, the archipelago is on a crossroads between two oceans, the Pacific and the Indian Ocean, and bridges two continents, Asia and Australia. The territory of the Republic of Indonesia stretches from $6^{\circ} 08^{\prime} \mathrm{N}$ latitude to $11^{\circ} 15^{\prime} \mathrm{S}$ latitude and from $94^{\circ} 45^{\prime} \mathrm{E}$ to $141^{\circ} 05^{\prime} \mathrm{E}$ longitude. Total Area of Indonesia is 1,919,440 square km (Land Area: 1,826,440 square km; Water Area: 93,000 square $\mathrm{km}$ ). The five main islands are: Sumatra $(473,606$ sq. $\mathrm{km})$; the most fertile and densely populated islands, Java/Madura 
$(132,107$ sq. km); Kalimantan, which comprises two-thirds of the island of Borneo (539,460 square $\mathrm{km})$; Sulawesi (189,216 square $\mathrm{km})$; and Irian Jaya (421,981 square $\mathrm{km}$ ), which is part of the world's second largest island, New Guinea. Indonesia's other islands are smaller in size (BPS, 2013).

Indonesia is the largest economy in Southeast Asia and is one of the emerging market economies of the world. The country is also a member of G-20 major economies and classified as a newly industrialized country (World Bank, 2017). It is the sixteenth largest economy in the world by nominal GDP and is the seventh largest in terms of GDP (PPP). Its GDP per capita, however, ranks below the world average. Indonesia still depends on domestic market, and government budget spending and its ownership of state-owned enterprises and the administration of prices of a range of basic goods including, rice, and electricity plays a significant role in Indonesia market economy, but since the 1990s, the majority of the economy has been controlled by private Indonesians and foreign companies (Adhi, 2015).

Imports consist of transactions in goods and services to a resident of a jurisdiction such as a nation from non-residents (Lequiller \& Blades, 2006). An import of a good occurs when there is a change of ownership from a non-resident to a resident. Imports of services consist of all services rendered by non-residents to residents. In national accounts, import includes and excludes specific "borderline" cases. In macroeconomic theory, the value of imports can be modeled as a function of the domestic absorption and the real exchange rate (Burda, 2005). There are two basic types of import: industrial and consumer goods and intermediate goods and services. Companies import goods and services to supply to the domestic market at a cheaper price and better quality than competing goods manufactured in the domestic market. Trinh et al (2008) explained that imported intermediate input was shown in the usual Keynesian foreign trade multiplier analysis. In an open economy, $\mathrm{Y}+\mathrm{M}=\mathrm{C}+\mathrm{I}+\mathrm{E}$; the external sector is combined inconsistently with the domestic sector in the circular flow. Where, Y stands for net national products (or net final demand) excluding intermediate products, while $\mathrm{M}$ stands for imported including intermediate products. On the other hand, Leontief's matrix multiplier is devoted entirely to the analysis of intermediate products in the circular flow, the Leontief system can regard the household sector as an industry whose output is labor income and inputs are consumption products; An analysis of the multiplier process via the consumption function.

From 2004 to 2012, imports to Indonesia tripled, as large portion of the population entered middle-class and propelled higher purchases of oil and consumption goods. However, starting in mid-2013, imports have been declining due to low commodity prices and weak domestic consumption and investment. Main imports products are oil and gas (around 17 percent of total imports), nuclear reactions, boilers, mechanical appliances (19 percent); iron and steel (5.4 percent), organic chemical materials (4.8 percent) and vehicles (4.5 percent). Main import partners are China (25 percent of the total imports), Japan (11 percent), Singapore (7.6 percent), Thailand (6.8 percent) and the United States (6.4 percent). Imports to Indonesia jumped 23.33 percent from a year earlier to US\$ 14.19 billion in October of 2017, following a 13.13 percent rise in the prior month and above market estimates of a 16 percent increase. Purchases of non-oil 
and gas rose 20.33 percent to US\$ 11.99 billion and those of oil and gas surged by 42.67 percent to US\$2.20 billion (Tradingeconomics, 2017).

This paper aimed to calculate, present and discuss on import components and the impact of final demand change on Indonesian imports -import multipliersusing Indonesian 36 sector input-output tables of years: 2000, 2005, 2010 and 2014 from World Input-Output Tables.

\section{LITERATURE REVIEW Import}

An import is a good brought into a jurisdiction, especially across a national border, from an external source. The party bringing in the good is called an importer (Joshi, 2009)). An import in the receiving country is an export from the sending country. Importation and exportation are the defining financial transactions of international trade. In international trade, the importation and exportation of goods are limited by import quotas and mandates from the customs authority. Imports consist of transactions in goods and services to a resident of a jurisdiction such as a nation from non-residents (Lequiller \& Blades, 2006). An import of a good occurs when there is a change of ownership from a non-resident to a resident. Imports of services consist of all services rendered by non-residents to residents. In national accounts, import includes and excludes specific "borderline" cases. In macroeconomic theory, the value of imports can be modeled as a function of the domestic absorption and the real exchange rate (Burda, 2005). There are two basic types of import: industrial and consumer goods and intermediate goods and services. Companies import goods and services to supply to the domestic market at a cheaper price and better quality than competing goods manufactured in the domestic market. Trinh et al (2008) explained that imported intermediate input was shown in the usual Keynesian foreign trade multiplier analysis.

\section{Multiplier}

In macroeconomics, a multiplier is a factor of proportionality that measures how much an endogenous variable changes in response to a change in some exogenous variable (see among others: Dornbusch \& Stanley, 1994; McConnell et al, 2011; Pindyck \& Rubinfeld, 2012). In monetary microeconomics and banking, the money multiplier measures how much the money supply increases in response to a change in the monetary base (see among others: Krugman \& Wells 2009; Mankiw, 2008). Multipliers can be calculated to analyze the effects of fiscal policy, or other exogenous changes in spending, on aggregate output. Other types of fiscal multipliers can also be calculated, like multipliers that describe the effects of changing taxes.

Literature on the calculation of Keynesian multipliers traces back to Kahn's description of an employment multiplier for government expenditure during a period of high unemployment (Kahn, 1931). At this early stage, Kahn's calculations recognize the importance of supply constraints and possible increases in the general price level resulting from additional spending in the national economy (Ahiakpor, 2000). Hall (2009) discusses the way that behavioral assumptions about employment and spending affect econometrically estimated Keynesian multipliers. 
The literature on the calculation of I-O multipliers traces back to Leontief (1951), who developed a set of national-level multipliers that could be used to estimate the economy-wide effect that an initial change in final demand has on an economy. Isard (1951) then applied input-output analysis to a regional economy. According to Richardson (1985), the first attempt to create regional multipliers by adjusting national data with regional data was Moore \& Peterson (1955) for the state of Utah. In a parallel development, Tiebout (1956) specified a model of regional economic growth that focuses on regional exports. His economic base multipliers are based on a model that separates production sold to consumers from outside the region to production sold to consumers in the region. The magnitude of his multiplier is based on the regional supply chain and local consumer spending.

In a survey of input-output and economic base multipliers, Richardson (1985) notes the difficulty inherent in specifying the local share of spending. He notes the growth of survey-based regional input-output models in the 1960s and 1970s that allowed for more accurate estimation of local spending, though at a large cost in terms of resources. To bridge the gap between resource intensive survey-based multipliers and "off-the-shelf" multipliers, Beemiller (1990) of the BEA describes the use of primary data to improve the accuracy of regional multipliers. The literature on the use and misuse of regional multipliers and models is extensive. Coughlin \& Mandelbaum (1991) provide an accessible introduction to regional I-O multipliers. They note that key limitations of regional I-O multipliers include the accuracy of leakage measures, the emphasis on shortterm effects, the absence of supply constraints, and the inability to fully capture interregional feedback effects.

Grady \& Muller (1988) argued that regional I-O models that include household spending should not be used and argue that cost-benefit analysis is the most appropriate tool for analyzing the benefits of particular programs. Mills (1993) noted the lack of budget constraints for governments and no role for government debt in regional IO models. As a result, in less than careful hands, regional I-O models can be interpreted to over-estimate the economic benefit of government spending projects. Hughes (2003) discussed the limitations of the application of multipliers and provides a checklist to consider when conducting regional impact studies. Harris (1997) discussed the application of regional multipliers in the context of tourism impact studies, one area where the multipliers are commonly misused. Siegfried, et al (2006) discussed the application of regional multipliers in the context of college and university impact studies, another area where the multipliers are commonly misused. Input-output analysis, also known as the inter-industry analysis, is the name given to an analytical work conducted by Leontief in the late 1930's. The fundamental purpose of the inputoutput framework is to analyze the interdependence of industries in an economy through market-based transactions. Input-output analysis can provide important and timely information on the interrelationships in a regional economy and the impacts of changes on that economy.

The notion of multipliers rests upon the difference between the initial effect of an exogenous change (final demand) and the total effects of a change. Direct effects measure the response for a given industry given a change in final demand for that same industry. Indirect effects represent the response by all local 
industries from a change in final demand for a specific industry. Induced effects represent the response by all local industries caused by increased (decreased) expenditures of new household income and inter-institutional transfers generated (lost) from the direct and indirect effects of the change in final demand for a specific industry. Total effects are the sum of direct, indirect, and induced effects.

\section{Import Multiplier}

In input-output model, multipliers were distinguished by output, income, employment and other value added. West (1990) defined total output multipliers as summation of initial, direct, indirect and induced effects of change in final demand. Initial effect of change in final demand to household income is initial effect of output multiply by direct requirement of household coefficients of income. Import multipliers can be defined as impact of direct, indirect and induced of change in final demand. It is hard to find literature on import multipliers, except one by Trinh et al. (2008).

\section{METHOD}

An input-output table records the "flows of products from each industrial sector considered as a producer to each of the sectors considered as consumers" (Miller \& Blair, 1985). It is an "excellent descriptive device" and a powerful analytical technique (Jensen, et al., 1979). In the production process, each of these industries uses products that were produced by other industries and produces outputs that will be consumed by final users (for private consumption, government consumption, investment and exports) and also by other industries, as inputs for intermediate consumption (Oosterhaven \& Stelder, 2007; Timmer, et.al, 2015). These transactions may be arrayed in an input-output table, as illustrated in table 1.

Table 1. Simplified National Input-Output

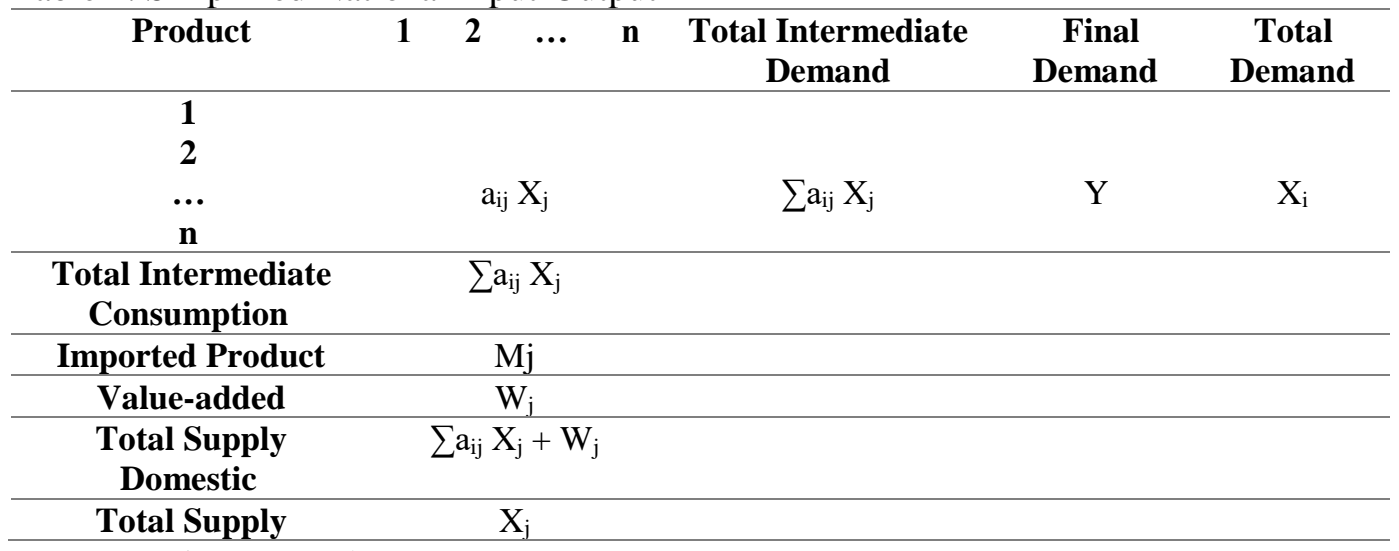

(Source: Timmer et al, 2015)

The columns of Table 1 provide information on the input composition of the total supply of each product $\mathrm{j}(\mathrm{Xj})$, this is comprised by the national production and also by imported products. The value of domestic product consists of intermediate consumption of several industrial inputs i plus value added. The interindustry transactions table is a nuclear part of this table, in the sense that it provides a detailed portrait of how the different economic activities are 
interrelated. Since, in this table, intermediate consumption is of the total-flow type, this implies that true technological relationships are being considered. In fact, each column of the intermediate consumption table describes the total amount of each input $i$ consumed in the production of output $j$, regardless of the geographical origin of that input.

The input-output interconnections illustrated in Table 1 can be translated analytically into accounting identities. On the demand perspective, if $\mathrm{Z}_{\mathrm{ij}}$ denotes the intermediate use of product $i$ by industry $j$ and $y_{i}$ denote the final use of product $i$, we may write, to each of the $n$ products:

$$
\mathrm{X}_{\mathrm{i}}=\mathrm{Z}_{\mathrm{i} 1}+\mathrm{Z}_{\mathrm{i} 2}+\ldots+\mathrm{Z}_{\mathrm{ii}}+\ldots+\mathrm{Z}_{\mathrm{in}}+\mathrm{y}_{\mathrm{i}}
$$

On the supply side, we know that:

$$
X_{j}=Z_{1 j}+Z_{2 j}+\ldots+Z_{j i}+\ldots+Z_{n j}+w_{j}+m_{j}
$$

In which $\mathrm{w}_{\mathrm{j}}$ stands for value added in the production of $j$ and $\mathrm{m}_{\mathrm{j}}$ for total imports of product $j$. Of course, it is required that, for $i=j, \mathrm{x}_{\mathrm{i}}=\mathrm{x}_{\mathrm{j}}$, i.e., for one specific product, the total output obtained in the use or demand perspective must equal the total output achieved by the supply perspective. These two equations can be easily related to the National Accounts' identities. In general term, equation (1) can be written as:

$$
x=\mathrm{A} x+y \text { or } x=(\mathrm{I}-\mathrm{A})^{-1} y
$$

National Input-Output Table of Indonesia for the year of 2000, 2005, 2010 and 2014 are available from World Input-Output Data Base (Timmer et al. 2015; 2016). Calculation on total input, imported input, import coefficients and import multipliers were based on 36 sectors classification of Indonesia National Tables.

Total input used to produce output could come from domestic and imported; $\mathrm{a}^{\mathrm{n}_{\mathrm{ij}}}=\mathrm{a}^{\mathrm{nn}} \mathrm{n}_{\mathrm{ij}}+\mathrm{a}^{\mathrm{nk}}{ }_{\mathrm{ij}}$, where: $\mathrm{a}_{\mathrm{ij}}$ = total input coefficient, $\mathrm{a}^{\mathrm{nn}}{ }_{\mathrm{ij}}=$ domestic input and $a^{n_{i j}}=$ imported input. Initial effect of import $=m_{j}$, direct effect of import $=\sum \mathrm{a}_{\mathrm{ij}} \mathrm{m}_{\mathrm{j}}$, indirect effect of import $=\sum \mathrm{b}_{\mathrm{ij}} \mathrm{m}_{\mathrm{j}}-\mathrm{m}_{\mathrm{j}}-\sum \mathrm{a}_{\mathrm{ij}} \mathrm{m}_{\mathrm{j}}$, total effect of import $=$ $\sum b_{i j} m_{j}$, type-1 import multipliers $=\left(\sum b_{i j} m_{j}\right) / m_{j}\left(\right.$ West, 1990). Note that $m_{j}$ is import output ratio, $a_{i j}$ is direct input coefficients, $b_{i j}$ is the element of open inverse of Leontief matrix (I-A) $)^{-1}$ in equation (3).

Sector classifications and Country abbreviations are available at Appendix-1 and Appendix-2.

\section{RESULT AND DISCUSSION Import Components}

Figure 1 depicts import component of input in Indonesian economy for the year of 2000, 2005, 2010 and 2014. In the year of 2000, from 0.5296 total input proportions, on average, 22.66 percent was imported and 77.34 percent was locally provided. Sectors that had less than 20 percent component imported, at the same time were the sector that had more than 80 percent locally provided, were Sector-1, Sector-3, Sector-5, Sector-20, Sector-22, Sector-23, Sector-27, Sector28, Sector-29, Sector-30, Sector-35, and Sector-36. Other sector had import component more than 20 percent.

In the year of 2005, from 0.5349 of total input proportions, on average, 22.22 percent was imported and 77.78 percent was locally provided. Sectors that had less than 20 percent imported component, at the same time were the sector that had more than 80 percent locally provided, were Sector-3, Sector-5, Sector-8, Sector-20, Sector-22, Sector-23, Sector-25, Sector-27, Sector-28, Sector-29, 
Sector-30, Sector-31, Sector-32, Sector-33 and Sector-35. Other sector had import component more than 20 percent.
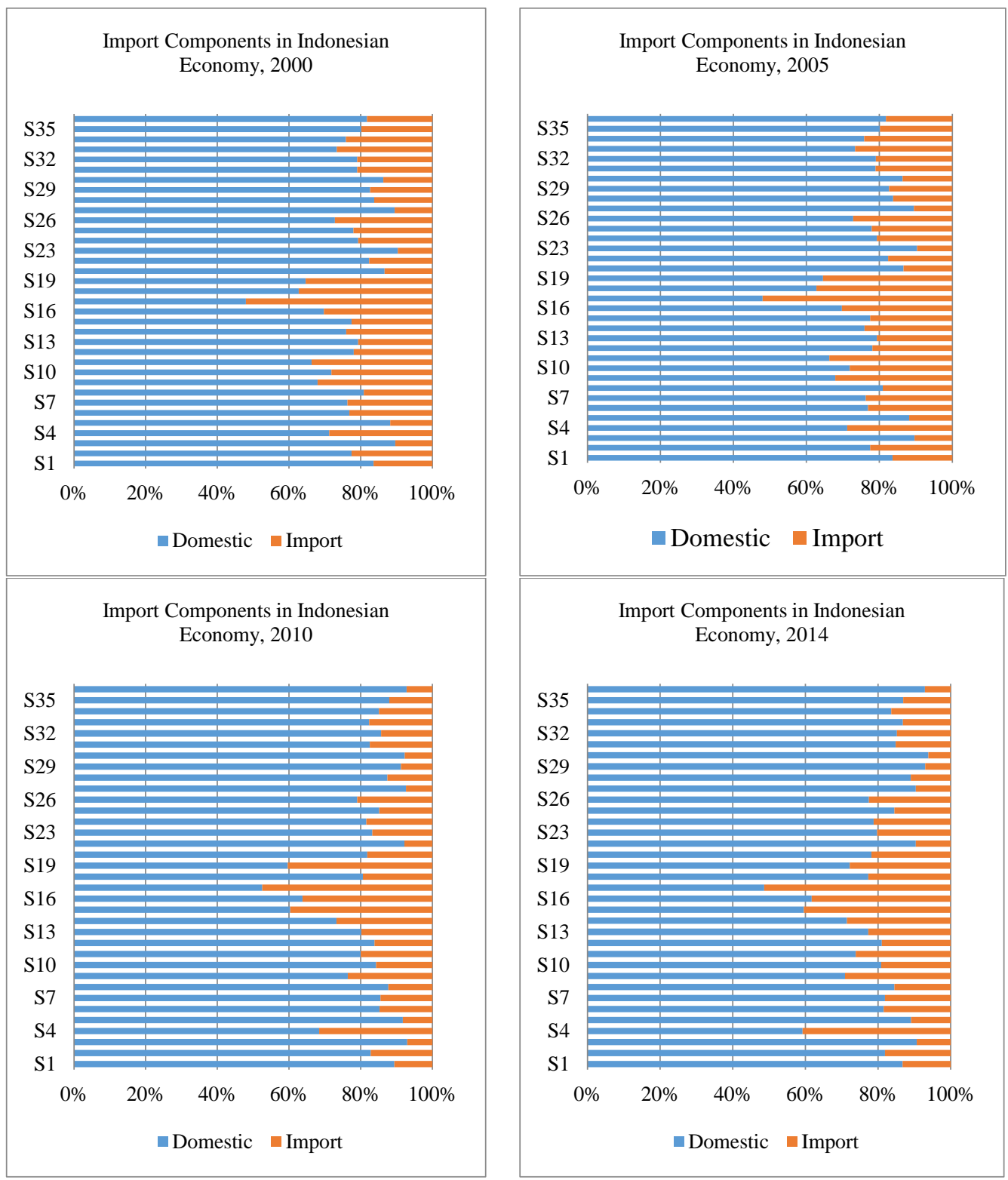

Figure 1. Import Components of Input in Indonesian Economy: 2000, 2005, 2010, 2014 Source: Processed from WIOT, 2017

In the year of 2010, from 0.5239 of total input proportions, on average, 18.23 percent was imported and 81.77 percent was locally provided. Sectors that had less than 20 percent component imported, at the same time were the sector that had more than 80 percent locally provided, were Sector-1, Sector-2, Sector-3, Sector-5, Sector-6, Sector-7, Sector-8, Sector-10, Sector-11, Sector-12, Sector-13, Sector-20, Sector-22, Sector-23, Sector-24, Sector-25, Sector-27, Sector-28, Sector-29, Sector-30, Sector-31, Sector-32, Sector-33, Sector-34, Sector-35, and Sector-36. Other sector had import component more than 20 percent.

In the year of 2014, from 0.5236 total input proportions, on average, 19.81 percent was imported and 80.19 percent was locally provided. Sectors that had 
less than 20 percent component imported, at the same time were the sector that had more than 80 percent locally provided, were Sector-1, Sector-2, Sector-3, Sector-5, Sector-6, Sector-7, Sector-8, Sector-10, Sector-12, Sector-20, Sector-22, Sector-25, Sector-27, Sector-28, Sector-29, Sector-30, Sector-31, Sector-32, Sector-33, Sector-34, Sector-35, and Sector-36. Other sector had import component more than 20 percent. In Australia and Japan, more than 80 percent of inputs were locally provided. Event, in China and USA more 90 percent of inputs were locally provided (Muchdie, 2017a; 2017b; Muchdie \& Sugema, 2017).

Total Indonesian imports were significantly increased from 2000 to 2014. In the year of 2000, total Indonesian import was US\$ 36,011 million, and increased to US\$ 61,670 million in 2005 , increased to US\$ 116,708 million in 2010 and US\$ 151,505 million in 2014.

Figure 2 (upper panel) depicts Indonesian import of input by sector for the year of 2000, 2005, 2010 and 2014. In the year of 2000, total Indonesian import was US\$36,011 million. Sectorally, the highest import was by Sector-25 (US\$ 4,179 million) and the lowest import was by Sector-23 (US $\$ 8$ million). Ten highest sector in import were Sector-1 (US\$ 1,223 million), Sector-3 (US\$ 2,445 million), Sector-4 (US\$2,704 million), Sector-8 (US\$ 1,382 million), Sector-9 (US\$1,527 million), Sector-11 (US\$ 1,407 million), Sector-13 (US\$ 1,214 million), Sector-24 (US\$3,490 million), Sector-25 (US\$ 4,179 million), and Sector (US\$2,955 million).

In the year of 2005, the highest sectoral import was by Sector-24 (US\$ 7,049). Ten highest sector in import were Sector-3 (US\$ 3,159 million), Sector-4 (US\$ 2,909 million), Sector-8 (US\$ 3,010 million, Sector-9 (US\$ 2,620 million), Sector-11 (US\$ 2,446 million), Sector-13 (US\$ 2,878 million), Sector-18 (US\$ 3,969 million), Sector-24 (US\$ 7,049 million), Sector-25 (US\$ 4,167 million, and Sector-26 (US\$ 4,230 million).

In the year 2010, the higher sectoral import was by Sector-24 (US\$24,973 million) and the smaller sectoral import was Sector-23 (US\$ 28 million). Ten highest sector in import were Sector-2 (US\$ 5,716 million), Sector-3 (US\$ 10,702 million), Sector-4 (US\$ 8,118 million), Sector-9 (US\$ 4,247 million), Sector-11 (US\$ 4,247 million), Sector-15 (US\$ 5,419 million), Sector-17 (US\$ 3,783 million), Sector-24 (US\$ 24,973 million), Sector-25 (US\$ 7,281 million) and Sector-26 (US\$7,302 million).

In the year 2014, the higher sectoral import was by Sector-24 (US\$ 34,974 million) and the smaller sectoral import was Sector-23 (US\$ 8 million). Ten highest sector in import were Sector-2 (US\$ 4,996 million), Sector-3 (US\$ 8,083 million), Sector-4 (US\$ 5,783 million), Sector-8 (US $\$ 4,896$ million), Sector-9 (US\$ 6,039 million), Sector-15 (US\$ 6,354 million), Sector-24 (US\$ 34,974 million), Sector-25 (US\$ 8,777 million) and Sector-26 (US\$11,796 million).

Figure 2 (lower panel) depicts origin of countries where Indonesia imported goods and services in million US\$ for the year of 2000, 2005, 2010 and 2014. Total imported for the year of 2000 was US\$ 36,011 million. In the year of 2000, the highest import came from Japan (15.25\%), followed by South Korea $(6.75 \%)$. Goods and services imported from Australia was US\$ 2,224 million (6.18\% of total import), from Brazil was US\$ 379 million (1.05\%), from China was US\$ 1,596 million (4.43\%), from Germany was US\$ 954 million (2.65\%), from UK was US\$ 736 million (2.04\%), from India was US\$ 554 million 
(1.54\%), from Netherland was US\$ 439 million (1.22\%), from Taiwan was US\$ 885 million (2.46\%), from the USA was US\$ 2,025 million (5.62\%) and the rest was from ROW (rest of the world).

In the year of 2005, total Indonesian import was US \$ 61,670 million; most of it was imported from Japan (11.13\%), South Korea (5.85\%), China (7.85\%), Australia (5.73\%), India (2.35\%), Germany (2.04\%), USA (3.15\%), Taiwan (1.68\%) and ROW (51.8\%). From US\$112,211 million Indonesian imports in the year of 2010, most of it imported from Japan (10.78\%), South Korea (6.48\%), China (11.48\%), Australia (4.01\%), Brazil (2.17\%), India (2.24\%), Germany (1.82\%), USA (3.57\%), Taiwan (2.37\%) and ROW (4.83\%).

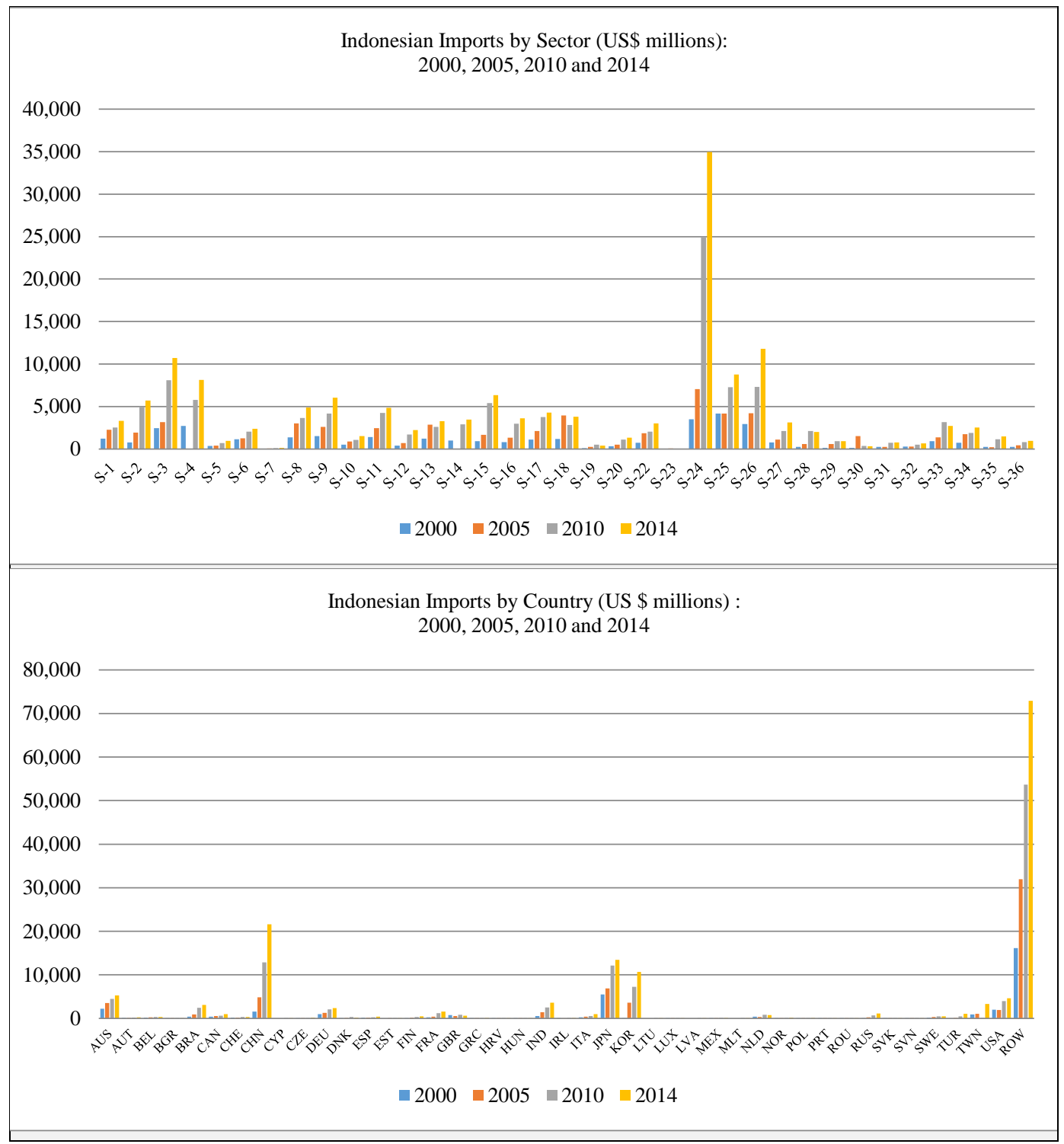

Figure 2. Indonesian Imports by Sector (Upper Panel) and by Country (Lower Panel): 2000, 2005, 2010 and 2014

Source: Processed from WIOT, 2017

Finally, from US\$ 151.505 million Indonesian import in 2014, most of them came from Japan (8.90\%), South Korea (7.04\%), China (14.27\%), Australia 
(3.48\%), Brazil (2.04\%), India (2.36\%), Germany (1.59\%), USA (3.06\%), Taiwan $(2.17 \%)$ and ROW (48.135). Please note that import from Australian declined during 2000 to 2014 , from $6.18 \%, 5.73 \%, 4.01 \%$ and $3.48 \%$ consecutively for the year of 2000, 2005, 2010, and 2014. The same case was applied for import from Germany, Japan, and the US. Meanwhile, Indonesian import from China steadily increases, from $4.43 \%$ in 2000 to $7.85 \%$ in 2010 and $12.47 \%$ in 2014.

\section{Import Multipliers}

Table 2 provides sectoral import multipliers in Indonesian economy for the year of 2000 and 2005. Import multipliers were classified as initial, direct, indirect and total effects of open matrix. Type- 1 multiplier is defined as a ratio of total to initial effects.

Tabel 2. Disaggregated Import Multipliers by Sector in Indonesian Economy: 2000, 2005

\begin{tabular}{|c|c|c|c|c|c|c|c|c|c|c|}
\hline \multirow[b]{2}{*}{ Sector } & \multicolumn{5}{|c|}{2000} & \multicolumn{5}{|c|}{2005} \\
\hline & Initial & Direct & Indirect & Total & Type-1 & Initial & Direct & Indirect & Total & Type-1 \\
\hline S-1 & 0.0367 & 0.1423 & 0.1205 & 0.2995 & 8.1697 & 0,0467 & 0,1118 & 0,0651 & 0,2236 & 4,7826 \\
\hline S-2 & 0.0329 & 0.1802 & 0.1132 & 0.3263 & 9.9235 & 0,0495 & 0,1400 & 0,1375 & 0,3269 & 6,6061 \\
\hline S-3 & 0.0675 & 0.0596 & 0.1153 & 0.2424 & 3.5909 & 0,0658 & 0,0378 & 0,0381 & 0,1418 & 2,1534 \\
\hline S-4 & 0.1841 & 0.0263 & 0.0051 & 0.2156 & 1.1705 & 0,1420 & 0,0292 & 0,0089 & 0,1801 & 1,2685 \\
\hline S-5 & 0.0744 & 0.0100 & 0.0008 & 0.0853 & 1.1463 & 0,0681 & 0,0211 & 0,0047 & 0,0939 & 1,3784 \\
\hline S-6 & 0.1548 & 0.0675 & 0.0380 & 0.2602 & 1.6815 & 0,1351 & 0,0828 & 0,0371 & 0,2551 & 1,8880 \\
\hline S-7 & 0.1200 & 0.0016 & 0.0004 & 0.1221 & 1.0173 & 0,1303 & 0,0014 & 0,0007 & 0,1324 & 1,0161 \\
\hline S-8 & 0.0958 & 0.0495 & 0.0570 & 0.2023 & 2.1123 & 0,1126 & 0,0991 & 0,1046 & 0,3162 & 2,8094 \\
\hline S-9 & 0.2088 & 0.0718 & 0.0207 & 0.3013 & 1.4431 & 0,2128 & 0,0845 & 0,0309 & 0,3282 & 1,5424 \\
\hline S-10 & 0.1848 & 0.0095 & 0.0021 & 0.1964 & 1.0623 & 0,1821 & 0,0096 & 0,0028 & 0,1945 & 1,0681 \\
\hline S-11 & 0.2251 & 0.0346 & 0.0094 & 0.2691 & 1.1954 & 0,2208 & 0,0353 & 0,0112 & 0,2673 & 1,2106 \\
\hline S-12 & 0.1240 & 0.0184 & 0.0016 & 0.1440 & 1.1618 & 0,1134 & 0,0207 & 0,0058 & 0,1399 & 1,2341 \\
\hline S-13 & 0.1482 & 0.1374 & 0.0593 & 0.3450 & 2.3273 & 0,1852 & 0,1656 & 0,0625 & 0,4133 & 2,2317 \\
\hline S-14 & 0.1564 & 0.0615 & 0.0094 & 0.2273 & 1.4534 & 0,1680 & 0,0518 & 0,0127 & 0,2325 & 1,3842 \\
\hline S-15 & 0.1557 & 0.0000 & 0.0000 & 0.1557 & 1.0000 & 0,1935 & 0,0030 & 0,0002 & 0,1967 & 1,0165 \\
\hline S-16 & 0.1967 & 0.0290 & 0.0034 & 0.2292 & 1.1651 & 0,2047 & 0,0297 & 0,0050 & 0,2394 & 1,1697 \\
\hline S-17 & 0.3483 & 0.0181 & 0.0015 & 0.3679 & 1.0562 & 0,3272 & 0,0228 & 0,0040 & 0,3540 & 1,0818 \\
\hline S-18 & 0.2005 & 0.0214 & 0.0081 & 0.2300 & 1.1472 & 0,2844 & 0,0144 & 0,0009 & 0,2996 & 1,0535 \\
\hline S-19 & 0.2362 & 0.0033 & 0.0019 & 0.2413 & 1.0219 & 0,2175 & 0,0078 & 0,0026 & 0,2279 & 1,0478 \\
\hline S-20 & 0.0905 & 0.0044 & 0.0008 & 0.0957 & 1.0573 & 0,0939 & 0,0082 & 0,0020 & 0,1041 & 1,1088 \\
\hline S-22 & 0.1311 & 0.0000 & 0.0000 & 0.1311 & 1.0000 & 0,1353 & 0,0000 & 0,0000 & 0,1353 & 1,0000 \\
\hline S-23 & 0.0301 & 0.0745 & 0.0283 & 0.1330 & 4.4185 & 0,0763 & 0,1026 & 0,0517 & 0,2306 & 3,0238 \\
\hline S-24 & 0.1350 & 0.0013 & 0.0013 & 0.1375 & 1.0187 & 0,1320 & 0,0163 & 0,0304 & 0,1787 & 1,3536 \\
\hline S-25 & 0.0866 & 0.0069 & 0.0124 & 0.1060 & 1.2230 & 0,0539 & 0,0079 & 0,0097 & 0,0716 & 1,3275 \\
\hline S-26 & 0.1686 & 0.4693 & 0.2812 & 0.9191 & 5.4507 & 0,1379 & 0,3415 & 0,1640 & 0,6434 & 4,6662 \\
\hline S-27 & 0.0616 & 0.1179 & 0.0945 & 0.2740 & 4.4497 & 0,0576 & 0,0991 & 0,0623 & 0,2189 & 3,8031 \\
\hline S-28 & 0.0590 & 0.0124 & 0.0102 & 0.0816 & 1.3838 & 0,0402 & 0,0478 & 0,0381 & 0,1260 & 3,1363 \\
\hline S-29 & 0.0508 & 0.0238 & 0.0149 & 0.0896 & 1.7623 & 0,0308 & 0,0596 & 0,0394 & 0,1298 & 4,2099 \\
\hline S-30 & 0.0239 & 0.0841 & 0.0543 & 0.1622 & 6.7979 & 0,0858 & 0,0617 & 0,0794 & 0,2269 & 2,6460 \\
\hline S-31 & 0.1049 & 0.0112 & 0.0052 & 0.1213 & 1.1564 & 0,0740 & 0,0957 & 0,0720 & 0,2417 & 3,2672 \\
\hline S-32 & 0.1045 & 0.0240 & 0.0169 & 0.1454 & 1.3920 & 0,0740 & 0,0007 & 0,0012 & 0,0758 & 1,0250 \\
\hline S-33 & 0.0954 & 0.0272 & 0.0197 & 0.1422 & 1.4917 & 0,0760 & 0,0008 & 0,0014 & 0,0782 & 1,0288 \\
\hline S-34 & 0.0994 & 0.0042 & 0.0035 & 0.1071 & 1.0772 & 0,1063 & 0,0118 & 0,0085 & 0,1265 & 1,1906 \\
\hline S-35 & 0.1073 & 0.0048 & 0.0015 & 0.1136 & 1.0589 & 0,0403 & 0,0216 & 0,0155 & 0,0773 & 1,9203 \\
\hline S-36 & 0.0586 & 0.0036 & 0.0016 & 0.0639 & 1.0899 & 0,0589 & 0,0131 & 0,0112 & 0,0832 & 1,4123 \\
\hline
\end{tabular}

Source: Processed from WIOT, 2017

In the year of 2000, there were some sectors with highest type-1 import multipliers, namely: Sector-2 (9.9235), Sector-1 (8.1697), Sector-30 (6.7979), Sector-26 (5.4507), Sector-27(4.4497) and Sector-23 (4.4185). The ratio of total to initial effect was more than 9 times in Sector-2, more than 8 times in Sector-1, more than 6 times in Sector-30, more than 5 times in Sector-26, more than 4 times in Sector-27 and in Sector-23. There were some other sectors with type-1 import multipliers more than 2, namely Sector-3 (5.5909) and Sector-13 (2.3273). Other sectors had type-1 import multipliers less than 2. Final demand changes in sectors that had type-1 import multipliers more than 2 should be avoided or anticipated as increased final demand in these sectors would increase import more than twice; in Sector-2 and Sector-3, even, increasing import more 8 times. 
In the year of 2005, there were some sectors with ratio between total effects to initial effects of import, which was called type-1 import multipliers, more than 2, namely: Sector-2 (6.6061), Sector-1 (4.7826), Sector-26 (4.6662), Sector-29 (4.2099), Sector-27 (3.8031), Sector-31 (3.2672), Sector-28 (3.1363), Sector-23 (3.0238), Sector-8 (2.8094), Sector-30 (2.6460), Sector-13 (2.2317) and Sector-3 (2.1534). Increasing final demand in these sectors would increase total import more than twice. Even, in Sector-2, Sector-1, Sector-26, and Sector-29 type-1 import multipliers were more than 4 ; meaning that the ratio between total effects and initial effects were more than 4 times.

Tabel 3. Disaggregated Import Multipliers by Sector in Indonesian Economy: 2010, 2014

\begin{tabular}{|c|c|c|c|c|c|c|c|c|c|c|}
\hline \multirow[b]{2}{*}{ Sector } & \multicolumn{5}{|c|}{2010} & \multicolumn{5}{|c|}{2014} \\
\hline & Initial & Direct & Indirect & Total & Type-1 & Initial & Direct & Indirect & Total & Type-1 \\
\hline S-1 & 0.0186 & 0.0871 & 0.0867 & 0.1924 & 10.3560 & 0.0231 & 0.1039 & 0.0885 & 0.2155 & 9.3384 \\
\hline S-2 & 0.0453 & 0.1613 & 0.1261 & 0.3326 & 7.3505 & 0.0476 & 0.1919 & 0.1282 & 0.3677 & 7.7182 \\
\hline S-3 & 0.0471 & 0.0342 & 0.0638 & 0.1451 & 3.0812 & 0.0626 & 0.0386 & 0.0709 & 0.1721 & 2.7469 \\
\hline S-4 & 0.1822 & 0.0235 & 0.0041 & 0.2097 & 1.1513 & 0.2344 & 0.0144 & 0.0013 & 0.2501 & 1.0668 \\
\hline S-5 & 0.0475 & 0.0221 & 0.0047 & 0.0742 & 1.5631 & 0.0623 & 0.0201 & 0.0031 & 0.0854 & 1.3716 \\
\hline S-6 & 0.0962 & 0.0586 & 0.0320 & 0.1868 & 1.9423 & 0.1198 & 0.0579 & 0.0258 & 0.2035 & 1.6992 \\
\hline S-7 & 0.1029 & 0.0017 & 0.0009 & 0.1055 & 1.0253 & 0.1282 & 0.0013 & 0.0007 & 0.1302 & 1.0160 \\
\hline S-8 & 0.0649 & 0.0501 & 0.0946 & 0.2097 & 3.2293 & 0.0817 & 0.0502 & 0.0890 & 0.2209 & 2.7048 \\
\hline S-9 & 0.1525 & 0.0959 & 0.0422 & 0.2906 & 1.9062 & 0.1870 & 0.1079 & 0.0373 & 0.3323 & 1.7768 \\
\hline S-10 & 0.1024 & 0.0241 & 0.0071 & 0.1336 & 1.3046 & 0.1245 & 0.0279 & 0.0078 & 0.1602 & 1.2865 \\
\hline S-11 & 0.1446 & 0.0470 & 0.0175 & 0.2090 & 1.4456 & 0.1886 & 0.0304 & 0.0093 & 0.2283 & 1.2103 \\
\hline S-12 & 0.1036 & 0.0127 & 0.0019 & 0.1181 & 1.1407 & 0.1207 & 0.0131 & 0.0015 & 0.1354 & 1.1215 \\
\hline S-13 & 0.1327 & 0.0260 & 0.0043 & 0.1630 & 1.2286 & 0.1512 & 0.0316 & 0.0046 & 0.1874 & 1.2394 \\
\hline S-14 & 0.1686 & 0.0199 & 0.0039 & 0.1924 & 1.1411 & 0.1798 & 0.0193 & 0.0033 & 0.2024 & 1.1257 \\
\hline S-15 & 0.2866 & 0.0415 & 0.0088 & 0.3369 & 1.1755 & 0.2916 & 0.0476 & 0.0105 & 0.3497 & 1.1991 \\
\hline$S-16$ & 0.2443 & 0.0545 & 0.0116 & 0.3105 & 1.2706 & 0.2576 & 0.0523 & 0.0113 & 0.3212 & 1.2467 \\
\hline S-17 & 0.3460 & 0.0792 & 0.0248 & 0.4500 & 1.3006 & 0.3734 & 0.0772 & 0.0217 & 0.4723 & 1.2650 \\
\hline S-18 & 0.0974 & 0.0304 & 0.0257 & 0.1536 & 1.5764 & 0.1134 & 0.0303 & 0.0212 & 0.1649 & 1.4541 \\
\hline S-19 & 0.2358 & 0.0041 & 0.0010 & 0.2409 & 1.0214 & 0.1647 & 0.0058 & 0.0024 & 0.1730 & 1.0503 \\
\hline S-20 & 0.1091 & 0.0061 & 0.0031 & 0.1183 & 1.0848 & 0.1308 & 0.0035 & 0.0017 & 0.1360 & 1.0398 \\
\hline S-22 & 0.0593 & 0.0000 & 0.0000 & 0.0593 & 1.0000 & 0.0731 & 0.0000 & 0.0000 & 0.0731 & 1.0000 \\
\hline S-23 & 0.0289 & 0.0695 & 0.0172 & 0.1156 & 4.0036 & 0.0348 & 0.0820 & 0.0177 & 0.1344 & 3.8602 \\
\hline S-24 & 0.1193 & 0.0016 & 0.0010 & 0.1219 & 1.0221 & 0.1370 & 0.0005 & 0.0003 & 0.1378 & 1.0064 \\
\hline S-25 & 0.0475 & 0.0200 & 0.0320 & 0.0995 & 2.0929 & 0.0496 & 0.0218 & 0.0364 & 0.1078 & 2.1736 \\
\hline S-26 & 0.1153 & 0.3579 & 0.1680 & 0.6412 & 5.5596 & 0.1264 & 0.3842 & 0.1675 & 0.6781 & 5.3659 \\
\hline S-27 & 0.0399 & 0.0769 & 0.0651 & 0.1819 & 4.5554 & 0.0521 & 0.1004 & 0.0844 & 0.2369 & 4.5464 \\
\hline S-28 & 0.0470 & 0.0183 & 0.0105 & 0.0757 & 1.6121 & 0.0412 & 0.0215 & 0.0147 & 0.0773 & 1.8782 \\
\hline S-29 & 0.0241 & 0.0559 & 0.0324 & 0.1124 & 4.6672 & 0.0192 & 0.0554 & 0.0326 & 0.1072 & 5.5861 \\
\hline S-30 & 0.0133 & 0.0480 & 0.0396 & 0.1008 & 7.5951 & 0.0105 & 0.0567 & 0.0445 & 0.1118 & 10.6094 \\
\hline S-31 & 0.0773 & 0.0032 & 0.0023 & 0.0829 & 1.0722 & 0.0670 & 0.0033 & 0.0024 & 0.0727 & 1.0857 \\
\hline S-32 & 0.0532 & 0.0069 & 0.0067 & 0.0668 & 1.2566 & 0.0547 & 0.0084 & 0.0086 & 0.0717 & 1.3108 \\
\hline S-33 & 0.0667 & 0.0185 & 0.0189 & 0.1041 & 1.5615 & 0.0495 & 0.0221 & 0.0225 & 0.0941 & 1.8999 \\
\hline S-34 & 0.0521 & 0.0067 & 0.0076 & 0.0663 & 1.2729 & 0.0570 & 0.0070 & 0.0080 & 0.0720 & 1.2637 \\
\hline S-35 & 0.0664 & 0.0026 & 0.0015 & 0.0704 & 1.0605 & 0.0719 & 0.0031 & 0.0017 & 0.0768 & 1.0678 \\
\hline S-36 & 0.0357 & 0.0067 & 0.0020 & 0.0444 & 1.2421 & 0.0353 & 0.0081 & 0.0022 & 0.0457 & 1.2936 \\
\hline
\end{tabular}

Source: Processed from WIOT, 2017

Table 3 provides sectoral import multipliers in Indonesian economy for the year of 2010 and 2014. In the year of 2010, there were sectors with ratio between total effects to initial effects of import, which was called type-1 import multipliers, more than 2, namely: Sector-1 (10.3560), Sector-2 (7.3505), Sector-3 (3.0812), Sector-8 (3.2293), Sector-23 (4.0036), Sector-26 (5.5595), Sector-27 (4.5554), Sector-29 (4.6672), and Sector-30 (7.5951). Increasing final demand in these sectors would increase total import more than twice. Even, in Sector-1, Sector-2, and Sector-30, increase in final demand would increase total import more than 4 times to initial imports.

In the year of 2014, there were sectors with ratio between total effects to initial effects of import, which was called type-1 import multipliers, more than 2 , namely: Sector-1 (9.3384), Sector-2 (7.7182), Sector-3 (2.7469), Sector-8 (2.7048), Sector-23 (3.8602), Sector-25 (2.1736), Sector-26 (5.3659), Sector-27 (4.5464), Sector-29 (5.5861), and Sector-30 (10.6094). Increasing final demand in 
these sectors would increase total import more than twice. Even, in Sector-1, Sector-2, and Sector-30 type-1 import multipliers were more than 7; meaning that the ration between total effects and initial effects were more than 7 times. From these results, it should be noted that sectors with type-1 import multipliers more than 2; meaning than the ration between total effects to initial effects more than 2, should be avoided, as an increase in final demand in these sectors would increase total import more than twice of initial effects.

Tabel 4. Import Multipliers by Country in Indonesian Economy: 2000, 2005, 2010, 2014

\begin{tabular}{|c|c|c|c|c|c|c|c|c|c|c|}
\hline \multirow[t]{2}{*}{ Country } & \multicolumn{5}{|c|}{2000} & \multicolumn{5}{|c|}{2005} \\
\hline & Initial & Direct & Indirect & Total & Type-1 & Initial & Direct & Indirect & Total & Type-1 \\
\hline AUS & 0,0065 & 0,0030 & 0,0018 & 0,0113 & 1,7477 & 0,0059 & 0,0026 & 0,0014 & 0,0099 & 1,6805 \\
\hline BRA & 0,0011 & 0,0005 & 0,0003 & 0,0019 & 1,7008 & 0,0015 & 0,0006 & 0,0004 & 0,0025 & 1,6522 \\
\hline $\mathrm{CHN}$ & 0,0046 & 0,0020 & 0,0012 & 0,0079 & 1,6930 & 0,0080 & 0,0034 & 0,0020 & 0,0135 & 1,6728 \\
\hline DEU & 0,0028 & 0,0012 & 0,0007 & 0,0046 & 1,6734 & 0,0021 & 0,0009 & 0,0005 & 0,0035 & 1,6639 \\
\hline FRA & 0,0008 & 0,0003 & 0,0002 & 0,0013 & 1,7200 & 0,0007 & 0,0003 & 0,0002 & 0,0012 & 1,6909 \\
\hline GBR & 0,0021 & 0,0009 & 0,0006 & 0,0036 & 1,6811 & 0,0009 & 0,0004 & 0,0002 & 0,0015 & 1,6395 \\
\hline IND & 0,0016 & 0,0007 & 0,0004 & 0,0028 & 1,7272 & 0,0024 & 0,0010 & 0,0006 & 0,0040 & 1,6820 \\
\hline JPN & 0,0160 & 0,0065 & 0,0042 & 0,0267 & 1,6697 & 0,0114 & 0,0045 & 0,0028 & 0,0188 & 1,6455 \\
\hline KOR & 0,0071 & 0,0031 & 0,0019 & 0,0121 & 1,7100 & 0,0060 & 0,0026 & 0,0016 & 0,0102 & 1,7012 \\
\hline NLD & 0,0013 & 0,0005 & 0,0003 & 0,0021 & 1,6774 & 0,0006 & 0,0002 & 0,0001 & 0,0010 & 1,6675 \\
\hline TWN & 0,0026 & 0,0011 & 0,0007 & 0,0043 & 1,6861 & 0,0017 & 0,0007 & 0,0004 & 0,0029 & 1,6843 \\
\hline USA & 0,0059 & 0,0025 & 0,0016 & 0,0100 & 1,6983 & 0,0032 & 0,0014 & 0,0008 & 0,0054 & 1,6749 \\
\hline ROW & 0,0525 & 0,0221 & 0,0128 & 0,0874 & 1,6652 & 0,0579 & 0,0237 & 0,0134 & 0,0951 & 1,6410 \\
\hline IMPORT & 0,1048 & 0,0445 & 0,0268 & 0,1760 & 1,6801 & 0,1024 & 0,0425 & 0,0245 & 0,1694 & 1,6536 \\
\hline \multirow[t]{2}{*}{ Country } & \multicolumn{5}{|c|}{2010} & \multicolumn{5}{|c|}{2014} \\
\hline & Initial & Direct & Indirect & Total & Type-1 & Initial & Direct & Indirect & Total & Type-1 \\
\hline AUS & 0,0031 & 0,0015 & 0,0009 & 0,0055 & 1,7803 & 0,0031 & 0,0015 & 0,0008 & 0,0054 & 1,7527 \\
\hline BRA & 0,0017 & 0,0008 & 0,0005 & 0,0029 & 1,7434 & 0,0018 & 0,0009 & 0,0005 & 0,0032 & 1,7640 \\
\hline $\mathrm{CHN}$ & 0,0089 & 0,0039 & 0,0024 & 0,0152 & 1,6996 & 0,0126 & 0,0054 & 0,0032 & 0,0211 & 1,6751 \\
\hline DEU & 0,0014 & 0,0006 & 0,0004 & 0,0024 & 1,7097 & 0,0014 & 0,0006 & 0,0003 & 0,0023 & 1,6727 \\
\hline FRA & 0,0008 & 0,0003 & 0,0002 & 0,0014 & 1,6881 & 0,0009 & 0,0004 & 0,0002 & 0,0016 & 1,6690 \\
\hline GBR & 0,0006 & 0,0002 & 0,0001 & 0,0010 & 1,6675 & 0,0004 & 0,0001 & 0,0001 & 0,0006 & 1,6518 \\
\hline IND & 0,0017 & 0,0008 & 0,0005 & 0,0031 & 1,7560 & 0,0021 & 0,0010 & 0,0005 & 0,0036 & 1,7289 \\
\hline JPN & 0,0084 & 0,0038 & 0,0024 & 0,0147 & 1,7495 & 0,0079 & 0,0035 & 0,0021 & 0,0134 & 1,7106 \\
\hline KOR & 0,0050 & 0,0022 & 0,0013 & 0,0086 & 1,7039 & 0,0062 & 0,0026 & 0,0015 & 0,0104 & 1,6661 \\
\hline NLD & 0,0006 & 0,0002 & 0,0001 & 0,0010 & 1,6637 & 0,0004 & 0,0002 & 0,0001 & 0,0007 & 1,6335 \\
\hline TWN & 0,0018 & 0,0008 & 0,0005 & 0,0032 & 1,7317 & 0,0019 & 0,0008 & 0,0005 & 0,0032 & 1,6850 \\
\hline USA & 0,0028 & 0,0013 & 0,0008 & 0,0048 & 1,7404 & 0,0027 & 0,0013 & 0,0007 & 0,0047 & 1,7207 \\
\hline ROW & 0,0408 & 0,0180 & 0,0106 & 0,0694 & 1,6998 & 0,0470 & 0,0204 & 0,0113 & 0,0787 & 1,6761 \\
\hline IMPORT & 0,0777 & 0,0346 & 0,0208 & 0,1331 & 1,7126 & 0,0884 & 0,0386 & 0,0219 & 0,1489 & 1,6851 \\
\hline
\end{tabular}

Source: Processed from WIOT, 2017

Table 4 provides country-import multipliers in Indonesian economy, namely: initial, direct, indirect and total effects, for the year 2000, 2005, 2010 and 2014. In average, type-1 country-import multipliers in Indonesian economy were: $1.6801,1.6536,1.7126$ and 1.6851 consecutively for the year of 2000, 2005, 2010 and 2014. In the year of 2000, Indonesian import multipliers from all over the world, totally 1.6801 times of initial import as it was multiplied by direct and indirect effects. The smallest type-1 country import multiplier in the year of 2000 was from the Rest of the World (1.6652) and the highest type-1 country import multiplier was from Australia (1.7477).

In the year of 2005, Indonesian import multipliers from all over the world, totally 1.6536 times of initial import. The smallest type-1 country import multiplier was imported from United Kingdom, GBR (1.6395) and the highest was from South Korea (1.7012). In the year of 2010, on average, Indonesian import multiplier from all over the world was 1.7126 . The smallest type- 1 country import multiplier was from Netherland (1.6637) and the highest type-1 country 
import multiplier was from Australia (1.7803). In the year of 2014, Indonesian import multiplier from all over the world, totally 1.6851 times of initial import. The smallest type-1 country import multiplier was import from Netherland (1.6335) and the highest type-1 country import multiplier was from Brazil (1.7640). From Table 3, one can see that type-1 Indonesia import multipliers during the year of 2000 to 2014 were not significantly different. There was also no significant different import from all over the world as well as from specific Indonesian trade partners.

\section{CONCLUSION}

From the discussion above, some conclusions could be drawn. Firstly, Indonesian import components of input were, on average, more than 20 percent; meaning that input that locally provided were less than 80 percent. Indonesian import of input had increased significantly from US\$ 36,011 million in 2000 to US\$ 151,505 million in 2014. Secondly, Indonesian imports have been dominated by Sector-3: Manufacture of food products, beverages and tobacco products, Sector-4: Manufacture of textiles, wearing apparel and leather products, Sector24: Construction, Sector-25: Wholesale and retail trade and repair, and Sector-26: Transportation and post services. Thirdly, by country of origin, Indonesian imports have been dominated by Japan, Korea, the USA, Australia, and China. Imports from Australia, Japan, and the US have been decreased significantly during the year of 2000-2014, but import from China has steadily increased during that years. Finally, highest sectoral import multipliers occurred if final demands change in Sector-1: Crop and animal production, forestry, fishing and aquaculture, Sector-2: Mining and quarrying, Sector-23: Water collection, treatment and supply; Sewerage; waste collection, treatment and disposal activities, and Sector-30: Real estate activities, but there was no significant difference of import multipliers for country origin of import.

\section{REFERENCES}

Adhi, A. (2015). 80 Persen Industri Indonesia Disebut Dikuasai Swasta. Retrieved from http://surabaya.tribunnews.com/2015/03/03/80-persen-industri-indo nesia-disebut-dikuasai-swasta.

Ahiakpor, J.C.W. (2000). Hawtrey on the Keynesian Multiplier: A Question of Cognitive Dissonance? History of Political Economy, 32(4), 889-908.

Beemiller, R.M. (1990). Improving Accuracy by Combining Primary Data with RIMS: Comment on Bourque. International Regional Science Review, 13 (1-2), 99-101.

BPS. (2013). Statistic of Maritime and Coastal Resources 2013. Jakarta: Badan Pusat Statistik.

Burda, W. (2005). Macroeconomics: A European Text. Fourth Edition, Oxford University Press.

Coughlin, C., \& Mandelbaum, T.B. (1991). A Consumer's Guide to Regional Economic Multipliers. Federal Reserve Bank of St. Louis Review, January/February 1991:19-32.

Dornbusch, R., \& Stanley, F. (1994). Macroeconomics. Sixth Edition. International Edition, McGraw-Hill. 
Grady, P., \& Muller, R. A. (1988). On the use and misuse of input-output based impact analysis in evaluation. The Canadian Journal of Program Evaluation, 2 (3): 49-61.

Hall, R. E. (2009). By How Much Does GDP Rise if the Government Buys More Output? NBER Working Paper 15496. National Bureau of Economic Research. Retrieved from: http://www.nber.org/papers/w15496.pdf.

Harris, P. (1997). Limitations on the use of regional economic impact multipliers by practitioners: An application to the tourism industry. The Journal of Tourism Studies, 8(2), 1-12.

Hughes, D. W. (2003). Policy uses of economic multipliers and impact analysis. Choices Publication of the American Agricultural Economics Association, Second Quarter. Retrieved from: http://www.choicesmagazine.org/2003-2/2003-2-06.htm

Isard, W. (1951). Inter-regional and Regional Input-Output Analysis: A Model of a Space-Economy. Review of Economics and Statistics, 33(4): 318-328.

Jensen, R.C., Mandeville, T.D., \& Karunaratne, N.D. (1979). Regional Economic Planning: Generation of Regional Input-Output Analysis, Croom Helm, and London.

Joshi, R. M. (2009). International Business. Oxford University Press, New Delhi and New York ISBN 0-19-568909-7.

Kahn, R. (1931). The Relation of Home Investment to Unemployment. Economic Journal, 41(162), 173-198. http://dx.doi.org/10.2307/2223697

Krugman, P. \& Wells, R. (2009). Economics, Worth Publisher, Duffield, UK.

Leontief, W.W. (1951). The Structure of American Economy 1919-1939. Second Edition, Harvard University Press, Cambridge.

Lequiller, F., \& Blades, D. (2006). Understanding National Accounts. Paris: OECD. pp. 139-143. Retrieved from http://www.oecd.org/std/UNA2014.pdf

Mankiw, N. G. (2008). Macroeconomics. Eight Edition, South-Western Publishing, Ohio, the USA.

McConnell, C., Brue, S., \& Flynn, S. (2011), Macroeconomics. McGraw-Hill Series Economics, 19th Edition. ISBN-13: 978-0077337728, ISBN-10: 0077337727.

Mills, E. C. (1993). The Misuse of Regional Economic Models. Cato Journal, 13(1), 29-39.

Miller, R., \& Blair, P. (1985). Input-Output Analysis - Foundations and Extensions. Prentice-Hall, Englewood Cliffs, New Jersey.

Moore, F.T., \& Petersen, J. (1955). Regional Analysis: An Inter-industry Model of Utah. Review of Economics and Statistics, 37, 368-383.

Muchdie, M. (2017a). Technical and Trade Coefficients in Indonesian and Australian Economies: A Comparison. Global Journal for Research Analysis, 6(11), 290-296. DOI: 10.15373/22778160. 
Muchdie, M. (2017b). Technical and Trade Coefficients in South Korean and Japanese Economies: Are They the Same? International Journal of Science and Research (IJSR), 6(11), 677-686. DOI: 10.21275/ART2017 8023.

Muchdie, M., \& Sugema. (2017). Technical and Trade Coefficients in China and in the USA Economies: Are They Different? International Journal of Advanced Research, 5(11), 377-390. DOI: 10.21474/IJAR01/5780.

Oosterhaven, J., \& Stelder, D. (2007), Regional and Interregional IO Analysis. Faculty of Economics and Business University of Groningen, the Netherlands, Retrieved from https://www.rug.nl/research/reg/research/ irios/download/regional-io-analysis.pdf.

Pindyck, R., \& Rubinfeld, D. (2012). Macroeconomics. The Pearson Series in Economics, 8th Edition, ISBN13:978-0132857123, ISBN-10: $013285712 \mathrm{X}$.

Richardson, H.W. (1985). Input-Output and Economic Base Multipliers: Looking Backward and Forward. Journal of Regional Science, 25 (4): 607-661.

Siegfried, J., Allen R., Sanderson, A.R., \& McHenry, P. (2006). The Economic Impact of Colleges and Universities. Working Paper No. 06-W12, Retrieved from http://www.accessecon.com/pubs/VUECON/vu06w12.pdf.

Tiebout, C.M. (1956). A Pure Theory of Local Expenditures. The Journal of Political Economy, 64(5): 416-424.

Timmer, M. P., Los, B., Stehrer, R \& de Vries, G. J. (2016). An Anatomy of the Global Trade Slowdown based on the WIOD 2016 Release. GGDC research memorandum number 162, University of Groningen, retrieved from http://www.ggdc.net/ publications/memorandum/gd162.pdf.

Timmer, M.P., Dietzenbacher, E., Los, B., Stehrer, R., \& de Vries, G.J. (2015). An Illustrated User Guide to the World Input-Output Database: the Case of Global Automotive Production. Review of International Economics, 23(3), 575-605. DOI:10.1111/roie.1217.

Tradingeconomics. (2017). Indonesian import, Tradingeconomics.com on Indonesian imports, Retrieved from: https:/www.tradingeconomics.com/ indonesia/imports.

Trinh, B., Hoa, P. L., \& Giang, B.C. (2008). Import multiplier in input-output analysis. Depocen Working Paper Series No. 2008/23.

West, G.R. (1990). Regional Trade Estimation: A Hybrid Approach. International Regional Science Review, 13(1\&2), 103-118.

World Bank. (2017). The World Bank in Indonesia: Having Maintained Political Stability, Indonesia is one of Asia Pasific's Most Vibrant Democracies and Is Emerging as a Confident Middle-Income Country. Retrieved from http://www.worldbank.org/en/country/indonesia/overview. 